\title{
Penggunaan Aplikasi Google Classroom Dalam Upaya Meningkatan Keaktifan Dan Hasil Belajar IPA Materi Kemagnetan Pada Siswa Kelas 9. Di SMP Negeri 1 Duhiadaa Semester 2 Tahun Pelajaran 2020/2021
}

\author{
Hafendi Rahman \\ SMP Negeri 1 Duhiadaa \\ hafendirahman73@Gmail.Com
}

\begin{abstract}
Received: 13 August 2021; Revised: 02 October 2021; Accepted: 14 December 2021
DOI: http://dx.doi.org/10.37905/aksara.8.1.55-64.2022
\end{abstract}

\begin{abstract}
Abstrak
Penelitian tindakan kelas ini bertujuan untuk mendeskripsikan peningkatan proses dan hasil belajar IPA materi kemagnetan siswa kelas 9.D SMP Negeri 1 Duhiadaa melalui penggunaan aplikasi Google Classroom. Penelitian ini dilaksanakan melalui dua siklus. Jenis penelitian yang dilaksanakan adalah Penelitian Tindakan Kelas dengan teknik pengumpulan data melalui lembar tes hasil belajar. Teknik analisa data menggunakan teknik desktiptif. Subjek dalam penelitian ini adalah siswa kelas 9.D SMP Negeri 1 Duhiadaa sebanyak 30 siswa. Hasil penelitian ini menunjukkan melalui penggunaan aplikasi Google Classroom dapat meningkatkan keaktifan dan hasil belajar siswa. Peningkatan keaktifan belajar siswa menunjukkan perolehan pada kondisi awal sebesar 36,67\% atau 11 siswa, pada siklus I persentase rata-rata pengamatan keaktifan siswa sebesar 60,00\% atau 18 siswa dan pada siklus II persentase rata-rata perilaku siswa sebesar $93,33 \%$ atau 28siswa. Peningkatan rata-rata hasil belajar siswa mengalami peningkatan dari 66,67 naik menjadi 73,93 pada siklus pertama, dan 84,67 pada siklus kedua, dengan tingkat ketuntasan belajar sebanyak 9 siswa $(30,00 \%)$ pada studi awal, meningkat menjadi $50 \%$ atau 15 siswa pada siklus pertama, dan 27 siswa atau 90,00\% pada siklus kedua. Dari penjelasan di atas dapat disimpulkan bahwa penggunaan aplikasi Google Classroom terbukti dapat meningkatkan proses dan hasil belajar IPA materi kemagnetan siswa kelas 9.D SMP Negeri 1 Duhiadaa Dari penjelasan di atas indikator keberhasilan pembelajaran telah tercapai pada siklus kedua, sehingga pelaksanaan perbaikan pembelajaran dinyatakan selesai dan tuntas pada siklus kedua.
\end{abstract}

Kata kunci: keaktifan, hasil belajar, google classroom

\section{PENDAHULUAN}

Sejak munculnya wabah virus Covid-19 di Indonesia, dampak bagi keberlangsungan pendidikan yang disebabkan oleh pandemi ini sangat dirasakan oleh masyarakat berdomisili di kota maupun di desa (Halal, 2020:48). Menurut Kemendikbud RI memutuskan bahwa seluruh kegiatan pembelajaran selama pandemi dilakukan secara daring (dalam jaringan). Berdasarkan Surat Edaran Nomor 4 Tahun 2020, tentang Pelaksanaan Kebijakan Pendidikan dalam Masa Darurat Penyebaran Coronavirus Disease (Covid-19), yang memuat pemberitahuan maupun arahan tentang pelaksanaan kegiatan pembelajaran dari rumah bagi seluruh jenjang pendidikan mulai dari pra-sekolah hingga perguruan tinggi.

Maraknya pandemi COVID-19 di Indonesia memberikan efek negatif yang besar terhadap sektor pendidikan di dalamnya. Meredam dampakCOVID-19 tersebut, maka dibutuhkan langkah-langkah yang strategis. Pertama yang perlu dilakukan adalah memberikan edukasi kepada para peserta didik dan praktisi pendidik. Dilakukan dengan sosialisasi secara intensif oleh dinas kesehatan tentang virus corona itu sendiri, baik dari aspek pencegahannya maupun cara menyikapinya. Wawasan ini diharapkan dapat mengurangi efek kekhawatiran berlebih yang dapat menyebabkan dampak traumatis pada peserta didik dan tentu juga para pendidik. 
Sebagian besar lembaga pendidikan sudah menerapkan sistem Pembelajaran Jarak Jauh (PJJ). Pola pengajaran ini mengikuti rekomendasi pemerintah yang harus dilaksanakan secara daring. Pembelajaran Jarak Jauh (PJJ) bisa menjadi solusi agar pembahasan materi dapat terus berlanjut (Fermiska dkk., 2020). Langkah selanjutnya yang harus dilakukan adalah pemanfaatan teknologi jaringan dan informasi dengan menggunakan internet atau social media. Di Indonesia, persentase pengguna internet mencapai hingga 64\% dari kalangan remaja usia 15-19 tahun. Pada umumnya, rentang usia ini cenderung diminati oleh kalangan pelajar (Pranajaya, 2018:82). Whatsapp Group merupakan alat untuk berkomunikasi yang sangat populer di kalangan pelajar, seluruh interaksi dapat dilakukan seperti, mengirim pesan, foto, audio, dan video. Dengan menggunakan aplikasi ini, proses pembelajaran jarak jauh tetap berlangsung dan berjalan dengan baik, sehingga tujuan pembelajaran yang akan dicapai dapat terwujud (Andi, 2018:25). Salah satu alternatif pembelajaran jarak jauh atau daring yaitu dengan pembelajaran e-learning. Pembelajaran e-learning dapat menunjang pendidik serta peserta didik untuk mengatasi aturan sosial distancing yang diterapkan oleh pemerintah pusat maupun daerah terkait pendemi Covid 19.

Melihat kondisi realita yang ada, ketika mengadakan observasi di SMP Negeri 1 Duhiadaa dalam mengikuti pembelajaran daring khususnya pelajaran IPA di kelas 9.D perlu adanya perhatian. Penggunaan metode penugasan mendominasi pelaksanaan kegiatan pembelajaran daring tersebut. Metode tersebut disampaikan secara terus menerus digunakan pada setiap pembelajaran sehingga mengakibatkan keaktifan peserta didik rendah, jenuh dan kurang antusias dalam mengikuti pelajaran IPA sehingga hasil belajar yang diperoleh siswa kelas 9.D dalam pembelajaran cenderung rendah. Nilai IPA pada kegiatan pra-siklus menunjukkan angka yang kurang memuaskan hanya terdapat 9 siswa $(30 \%)$ yang dinyatakan tuntas dengan perolehan nilai rata-rata secara klasikal sebesar 66,67 sedangkan $\mathrm{KKM}=76$.

Dalam masa pandemi COVID-19 saat ini, pembelajaran yang dilakukan secara daring memanfaatkan teknologi informasi sebagai media untuk pelaksanaan pembelajaran Salah satu metode pembelajaran online yang saat ini sedang berkembang dan mulai digunakan adalah Google Classroom. Google Classroom adalah aplikasi khusus yang digunakan untuk pembelajaran online yang dapat dilakukan dari jarak jauh sehingga memudahkan guru untuk membuat, mengelompokkan dan membagikan tugas selain itu guru dan siswa bisa setiap saat melakukan kegiatan pembelajaran melalui kelas online Google Classroom dan siswa nantinya juga dapat belajar, menyimak, membaca dan mengirim tugas dari jarak jauh. Dalam proses pembelajaran melalui Google Classroom siswa diberi materi sehingga siswa langsung dapat memahami materi yang disampaikan guru melalui Google Classroom tersebut. Selain itu siswa juga diberi penugasan oleh guru dan mengirimkan hasil laporannya ke Google Classroom. Google Classroom menjadi salah satu alternatif untuk memberikan materi dan soal-soal tanpa menggunakan media cetak.

\section{KAJIAN PUSTAKA}

Pembelajaran daring atau yang dikenal dengan istilah E-learning merupakan pembelajaran yang memanfaatkan teknologi. Menurut Dimyati (2017 :82) menjelaskan bahwa pembelajaran daring atau yang dikenal dengan istilah e learning merupakan bentuk pemanfaatan teknologi dalam mendukung proses belajar mengajar jarak jauh. Hal 
ini meningkat perubahan gaya belajar yang semakin pesat. Berikut pengertian e-learning dalam berbagai sudut pandang para ahli : Pengertian e-learning menurut (Mutia, 2013:58) dalam jurnalnya mengatakan bahwa e-learning berasal dari dua kata yakni "e" dan "learning". "e" merupakan singkatan dari electorinc dan learning adalah pembelajaran. Jadi e-learning merupakan pembelajaran yang memanfaatkan teknologi dengan menggunakan media elektronik berupa komputer, laptop maupun handphone selama pembelajaran berlangsung. Selain itu Menurut Rosenberg dalam jurnal (Ucu dkk., 2018:92) e-learning merujuk pada penggunaan teknologi internet dalam mengirimkan serangkaian solusi yang mampu meningkatkan pengetahuan dan keterampilannya.

Sedangkan menurut Sutabri dalam jurnal (Agusli \& Azianah, 2014:19) menyatakan bahwa $e$-learning merupakan cara terbaru dalam proses belajar mengajar, $e$ learning lebih merujuk kepada pembelajaran yang di dukung melalui web sehingga dapat dilakukan didalam kelas sebagai pendukung pengajaran tradisional, dalam mengakses $e$ learning dapat dilakukan baik itu di rumah atau di dalam ruang kelas, juga dapat dilakukan dalam ruang kelas virtual, dimana semua kegiatan dilakukan online dan pelaksanaan kelas tidak melakukannya secara fisik langsung. Selanjutnya menurut (Abdullah, 2018:48) e-learning adalah proses pembelajaran dimana proses belajar siswa memudahkan siswa dalam belajar dengan memanfaatkan internet. Oleh karena itu, memungkinkan siswa dalam mempelajari hal-hal yang baru dengan mudah karena melalui e-learning mereka dapat memperoleh visualisasi sehingga pembelajaran dengan menggunakan e learning merupakan bagian penting dari pembelajaran siswa.

Pembelajaran daring menurut (Rigianti, 2020:78) adalah cara baru dalam pembelajaran dengan memanfaatkan perangkat elektronik berupa gawai atau laptop khususnya pada akses internet dalam penyampaiannya dalam pembelajaran, sehingga pembelajaran daring sepenuhnya bergantung kepada akses jaringan internet. Sedangkan menurut (Imania \& Bariah, 2019) pembelajaran dalam jaringan atau istilahnya (daring) merupakan salah satu bentuk penyampaian pembelajaran secara konvensional kemudian dituangkan kedalam format digital melalui internet. Sehingga pembelajaran daring sebagai satu satunya media pembelajaran yang dapat menyampaikan materi antara guru dan siswa selama masa darurat pandemic covid-19 ini. Sementara itu, menurut (Made Yeni Suranti, 2020:15) Pembelajaran jarak jauh atau daring merupakan bentuk pemanfaatan teknologi, dimana pembelajaran menggunakan akses internet untuk mengatasi berbagai tugas yang telah diberikan oleh pendidik.

Berdasarkan pernyataan di atas dapat disimpulkan bahwa pembelajaran daring merupakan sebuah cara terbaru dengan bentuk penyampaian pembelajaran konvensional dengan memanfaatkan berbagai perangkat elektronik sebagai media pembelajaran dalam menyampaikan materi. Dengan penggunaan model pembelajaran ini memiliki potensi untuk mendukung revolusi pembelajaran,

\section{a. Pengertian Google Classroom}

Google Classroom merupakan sebuah aplikasi yang memungkinkan terciptanya ruang kelas di dunia maya. Selain itu, Google Classroom bisa menjadi sarana distribusi tugas, submit tugas bahkan menilai tugas-tugas yang dikumpulkan (Herman, 2014:85). Dengan demikian, aplikasi ini dapat membantu memudahkan guru dan siswa dalam melaksanakan proses belajar dengan lebih mendalam. Hal ini disebabkan karena baik 
siswa maupun guru dapat mengumpulkan tugas, mendistribusikan tugas, menilai tugas di rumah atau dimanapun tanpa terikat batas waktu atau jam pelajaran.

Google Classroom sesungguhnya dirancang untuk mempermudah interaksi guru dan siswa dalam dunia maya. Aplikasi ini memberikan kesempatan kepada para guru untuk mengeksplorasi gagasan keilmuan yang dimilikinya kepada siswa. Guru memliki keleluasaan waktu untuk membagikan kajian keilmuan dan memberikan tugas mandiri kepada siswa selain itu, guru juga dapat membuka ruang diskusi bagi para siswa secara online. Namun demikian, terdapat syarat mutlak dalam mengaplikasikan Google Classroom yaitu membutuhkan akses internet yang mumpuni.

Aplikasi Google Classroom dapat digunakan oleh siapa saja yang tergabung dengan kelas tersebut. Kelas tersebut adalah kelas yang didesain oleh guru yang sesuai dengan kelas sesungguhnya atau kelas nyata di sekolah. Terkait dengan anggota kelas dalam Google Classroom Herman (2014:89) menjelaskan bahwa Google Classroom menggunakan kelas tersedia bagi siapa saja yang memiliki Google Apps for Education, serangkaian alat produktivitas gratis termasuk gmail, dokumen, dan drive.

Hal ini sejalan dengan pendapat Herman (2014:91) yang memaparkan bahwa dalam Google Classroom kelas dirancang untuk membantu guru membuat dan mengumpulkan tugas tanpa kertas, termasuk fitur yang menghemat waktu seperti kemampuan untuk membuat salinan google dokumen secara otomatis bagi setiap siswa. Kelas juga dapat membuat folder drive untuk setiap tugas dan setiap siswa, agar semuanya tetap teratur.

b. Langkah pengaplikasian Google Classroom

Mengaplikasikan google clasroom tentunya bukan hal mudah bagi guru yang tidak memiliki kemampuan di bidang teknologi informasi. Namun, sesungguhnya mengaplikasikan Google Classroom dapat dipelajari dengan memperhatikan langkahlangkah berikut ini.

1) Buka website google kemudian masuk pada laman Google Classroom

2) Pastikan Anda memiliki akun Google Apps for Education. Kunjungi classroom.google.com dan masuk. Pilih apakah Anda seorang guru atau siswa, lalu buat kelas atau gabung ke kelas.

3) Jika Anda administrator Google Apps, Anda dapat menemukan informasi lebih lanjut tentang cara mengaktifkan dan menonaktifkan layanan di Akses ke Kelas.

4) Guru dapat menambahkan siswa secara langsung atau berbagi kode dengan kelasnya untuk bergabung. Hal ini berarti sebelumnya guru di dalam kelas nyata (di sekolah) sudah memberitahukan kepada siswa bahwa guru akan menerapkan google clasroom dengan syarat setiap siswa harus memiliki email pribadi dengan menggunakan nama lengkap pemiliknya (tidak menggunakan nama panggilan/samaran).

5) Guru memberikan tugas mandiri atau melemparkan forum diskusi melalui laman tugas atau laman diskusi kemudian semua materi kelas disimpan secara otomatis ke dalam folder di google drive.

6) Selain memberikan tugas, guru juga dapat menyampaikan penguman atau informasi terkait dengan mata pelajaran yang akan dipelajari oleh siswa di kelas nyata pada laman tersebut. Siswa dapat bertanya kepada guru ataupun kepada siswa lain dalam kelas tersebut terkait dengan informasi yang disampaikan oleh guru.

7) Siswa dapat melacak setiap tugas yang hampir mendekati batas waktu pengumpulan di laman Tugas, dan mulai mengerjakannya cukup dengan sekali klik. 
8) Guru dapat melihat dengan cepat siapa saja yang belum menyelesaikan tugas, serta memberikan masukan dan nilai langsung di Kelas.

\section{METODE PENELITIAN}

Dalam penilitian ini penulis mengambil lokasi di SMP SMP Negeri 1 Duhiadaa yang beralamat di Jl Sawah Besar Desa Duhiadaa Kabupaten Pohuwato. Provinsi Gorontalo Peneliti mengambil lokasi atau tempat ini dengan pertimbangan bekerja pada sekolah tersebut, sehingga memudahkan dalam mencari data, peluang waktu yang luas dan subjek penelitian yang sangat sesuai dengan profesi peneliti sebagai tenaga pengajar IPA di sekolah tersebut.

Subjek penelitian ini adalah siswa kelas 9.D SMP SMP Negeri 1 Duhiadaa pada semester 2 tahun pelajaran 2020/2021 dengan jumlah siswa sebanyak 30 siswa,

Teknik pengumpulan data yang digunakan dalam penelitian ini adalah tes hasil belajar, observasi dan dokumentasi.

Pelaksanaan Penelitian Tindakan Kelas (PTK) ini dilaksanakan dalam siklus I sampai siklus ke-n. Tiap siklus dilaksanakan sesuai dengan refleksi dari siklus sebelumnya. Prosedur pelaksanaan dalam tahap ini meliputi (1) Perencanaan (2) Pelaksanaan (3) Pengamatan (4) Refleksi

Tindakan akan dihentikan bila kriteria keberhasilan telah tercapai. Adapun kriteria keberhasilan tindakan tersebut adalah :

1. Proses pembelajaran dinyatakan tuntas apabila $85 \%$ dari jumlah siswa dinyatakan tuntas. Siswa dinyatakan tuntas apabila memperoleh nilai minimal sama dengan kriteria ketuntasan minimal (KKM) yang telah ditetapkan oleh sekolah, yaitu 76,00.

2. Peningkatan aktivitas belajar siswa minimal $85 \%$ siswa dinyatakan meningkat kekatifan belajarnya.

\section{HASIL DAN PEMBAHASAN}

\section{Kondisi Awal}

Sebelum melaksanakan penelitian aplikasi Google Classroom, peneliti terlebih dahulu melakukan observasi pembelajaran dan wawancara dengan guru IPA yang mengajar kelas 9.D untuk mengetahui permasalahan-permasalahan yang dihadapi guru dalam proses pembelajaran di kelas. Berdasarkan hasil observasi pembelajaran di kelas, dapat dikemukakan gambaran umum permasalahan yang dihadapi guru dalam proses pembelajaran IPA di kelas 9.D SMP Negeri 1 Duhiadaa Diantaranya sebagai berikut:

a. Pembelajaran di kelas masih menggunakan metode penugasan dan bersifat teachercenter sehingga keterlibatan siswa dalam proses pembelajaran kurang optimal dan siswa menjadi pembelajar pasif karena hanya menggunakan metode penugasan.

b. Keterlibatan siswa dalam proses pembelajaran masih kurang optimal, guru kurang melakukan inovasi pembelajaran terutama penggunaan sumber belajar yang hanya berorientasi pada buku paket dan modul pembelajaran yang dibagikan kepada siswa.

Penjelasan mengenai hasil kegiatan pada kondisi awal penelitian tindakan kelas sebagaimana dijelaskan di bawah ini. 


\section{Rekapitulasi Hasil Tes Formatif Kondisi Awal}

\begin{tabular}{|c|c|c|c|c|}
\hline \multirow{2}{*}{ No } & \multirow{2}{*}{ Kriteria Ketuntasan } & \multicolumn{2}{|c|}{ Kondisi Awal } & \multirow{2}{*}{ Ket } \\
\hline & & Jumlah & $\%$ & \\
\hline 1 & Tuntas & 9 & 30,00 & \\
\hline \multirow[t]{6}{*}{2} & Belum Tuntas & 21 & 70,00 & \\
\hline & Jumlah & 30 & 100 & \\
\hline & Nilai terendah & \multicolumn{2}{|c|}{$\mathbf{5 0 , 0 0}$} & \\
\hline & Nilai tertinggi & \multicolumn{2}{|c|}{90,00} & \\
\hline & Rata - rata & \multicolumn{2}{|c|}{66,67} & \\
\hline & Ketuntasan & \multicolumn{2}{|c|}{30,00} & \\
\hline
\end{tabular}

Dari tabel di atas dapat dijelaskan bahwa nilai rata-rata sebesar 66,67 dengan siswa tuntas sebesar $30 \%$ atau 9 siswa, dengan siswa belum tuntas atau mendapat nilai kurang dari KKM sebesar 76,00 sebanyak 21 siswa atau 70,00\% dan angka ketuntasan klasikal sebesar $30,00 \%$.

\section{Siklus Pertama}

Penelitian tindakan kelas meningkatkan hasil belajar IPA dengan menggunakan aplikasi Google Classroom pada siklus 1 di Kelas 9.D SMP Negeri 1 Duhiadaa dilaksanakan dalam 2 pertemuan. Alokasi waktu untuk masing-masing pertemuan adalah $2 \times 40$ menit.

Penjelasan mengenai hasil kegiatan pada siklus pertama penelitian tindakan kelas sebagaimana dijelaskan di bawah ini.

Rekapitulasi Hasil Tes Formatif Siklus Pertama

\begin{tabular}{|c|l|c|c|l|}
\hline \multirow{2}{*}{ No } & \multirow{2}{*}{ Kriteria Ketuntasan } & \multicolumn{2}{|c|}{ Kondisi Awal } & \multirow{2}{*}{ Ket } \\
\cline { 3 - 4 } & & Jumlah & $\mathbf{\%}$ & \\
\hline 1 & Tuntas & 15 & 50,00 & \\
\hline 2 & Belum Tuntas & 15 & 50,00 & \\
\hline & Jumlah & $\mathbf{3 0}$ & $\mathbf{3 0}$ & \\
\hline & Nilai terendah & $\mathbf{6 0 , 0 0}$ & \\
\hline & Nilai tertinggi & $\mathbf{9 0 , 0 0}$ & \\
\hline & Rata - rata & $\mathbf{7 3 , 9 3}$ & \\
\hline & Ketuntasan & $\mathbf{5 0 , 0 0}$ & \\
\hline
\end{tabular}

Dari tabel di atas dapat dijelaskan bahwa nilai rata-rata sebesar 73,93 dengan siswa tuntas sebesar 50,00\% atau 15 siswa, dengan siswa belum tuntas atau mendapat nilai kurang dari KKM sebesar 76,00 sebanyak 15 siswa atau 50,00\% dan angka ketuntasan klasikal sebesar 50,00\%.

Data di atas menunjukkan dalam siklus I ini menunjukkan bahwa hasil penelitian pada siklus pertama belum sesuai dengan indikator yaitu minimal $85 \%$ dari jumlah seluruh siswa dinyatakan tuntas atau mendapat nilai minimal sama dengan KKM 76.

Siklus II

Penelitian tindakan kelas penerapan aplikasi Google Classroom dilaksanakan dalam 2 kali pertemuan. Alokasi waktu untuk masing-masing pertemuan adalah 2 x 40 
menit, tes siklus II dilaksanakan pada pertemuan terakhir siklus II sekitar 20 menit terakhir sebelum proses pembelajaran selesai.

Penjelasan mengenai hasil kegiatan pada siklus dua penelitian tindakan kelas sebagaimana dijelaskan di bawah ini.

\section{Rekapitulasi Hasil Tes Formatif Siklus Kedua}

\begin{tabular}{|l|l|l|l|l|}
\hline \multirow{2}{*}{ No } & \multirow{2}{*}{ Kriteria Ketuntasan } & \multicolumn{2}{|c|}{ Kondisi Awal } & Ket \\
\cline { 3 - 5 } & & Jumlah & $\mathbf{\%}$ & \\
\hline 1 & Tuntas & 27 & 90,00 & \\
\hline 2 & Belum Tuntas & 3 & 10,00 & \\
\hline & Jumlah & $\mathbf{3 0}$ & $\mathbf{1 0 0}$ & \\
\hline & Nilai terendah & $\mathbf{7 0 , 0 0}$ & \\
\hline & Nilai tertinggi & $\mathbf{1 0 0 , 0 0}$ & \\
\hline & Rata - rata & $\mathbf{8 4 , 6 7}$ & \\
\hline & Ketuntasan & $\mathbf{9 0 , 0 0}$ & \\
\hline
\end{tabular}

Dari tabel di atas dapat dijelaskan bahwa nilai rata-rata sebesar 84,67 dengan siswa tuntas sebesar 90,00\% atau 27 siswa, dengan siswa belum tuntas atau mendapat nilai kurang dari KKM sebesar 76,00 sebanyak 3 siswa atau $100 \%$ dan angka ketuntasan klasikal sebesar 90,00\%. Data di atas menunjukkan dalam siklus I ini menunjukkan bahwa hasil penelitian pada siklus kedua telah memenuhi indikator yaitu minimal $85 \%$ dari jumlah seluruh siswa dinyatakan tuntas atau mendapat nilai minimal sama dengan KKM 76 sehingga proses perbaikan pembelajaran melalui kegiatan penelitian tindakan kelas dinyatakan selesai dan tuntas pada siklus kedua

\section{Pembahasan}

Keberhasilan proses pembelajaran IPA materi kemagnetan dengan menggunakan aplikasi Google Classroom dapat dilihat dari hasil analisis data hasil penelitian yang telah dilakukan dalam 2 siklus sebagaimana dijelaskan di bawah ini.

Berdasarkan hasil tes evaluasi, nampak terjadi peningkatan hasil belajar siswa dari kondisi awal, siklus I ke siklus II. Persentase rata-rata nilai tes siswa pada siklus I ke siklus II untuk tiap indikator hasil belajar juga mengalami peningkatan. Hal ini dapat dilihat pada tabel berikut ini.

\section{Peningkatan Nilai, dan Ketuntasan Belajar Siswa pada Pra Siklus, Siklus I dan} Siklus II

\begin{tabular}{|l|l|l|l|l|l|l|}
\hline \multirow{2}{*}{ Siklus } & \multirow{2}{*}{ Nilai } & \multicolumn{4}{|l|}{ Ketuntasan } & \multirow{2}{*}{ Ket } \\
\cline { 3 - 6 } & & Tuntas & $\%$ & Belum Tuntas & $\%$ & \\
\hline Awal & 66,67 & 9 & 30,00 & 21 & 70,00 & \\
\hline Siklus I & 73,93 & 15 & 50,00 & 15 & 50,00 & \\
\hline Siklus II & 84,67 & 27 & 90,00 & 3 & 10,00 & \\
\hline
\end{tabular}

Persentase peningkatan hasil belajar IPA siswa dari kondisi awal, siklus pertama ke siklus kedua jika disajikan dalam grafik adalah sebagai berikut: 


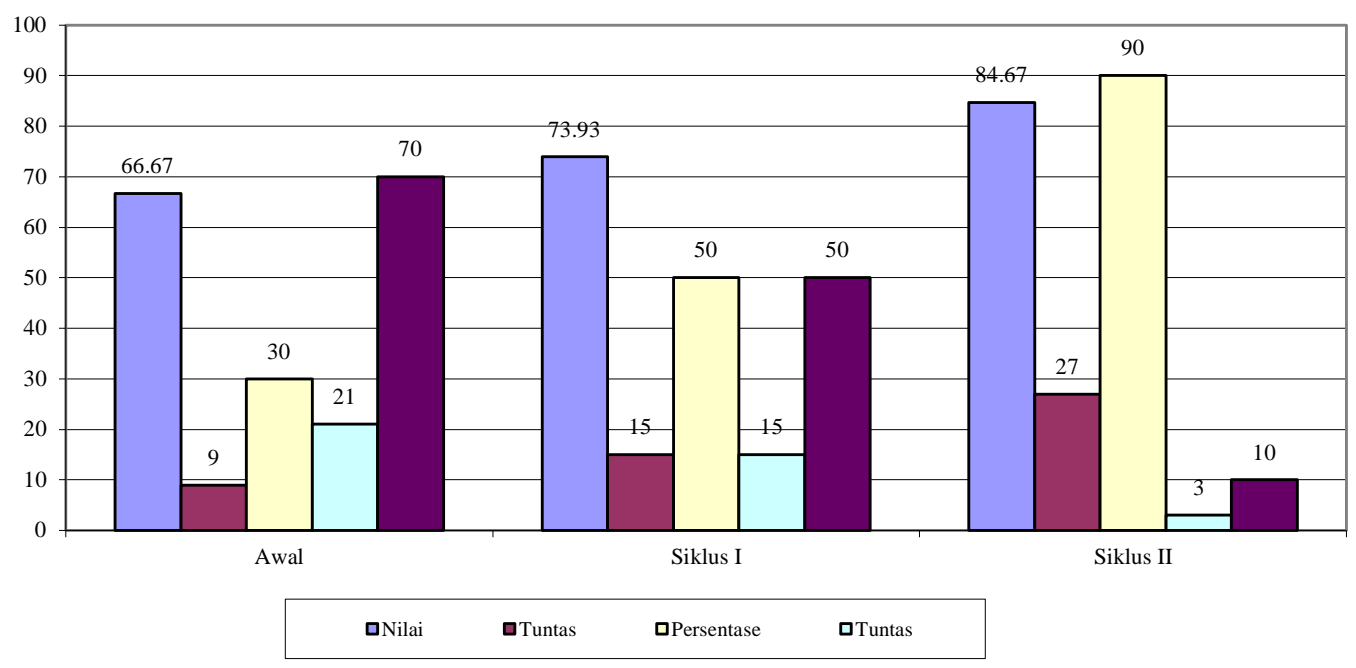

Gambar 4.1 Peningkatan Nilai, dan Ketuntasan Belajar Siswa pada Pra Siklus, Siklus I dan Siklus II

Dari grafik dan tabel di atas menunjukkan bahwa pelaksanaan menggunakan aplikasi Google Classroom pada pembelajaran IPA di kelas 9.D Semester 2 Tahun Pelajaran 2020/2021 dapat meningkatkan hasil belajar ini ditunjukkan dengan peningkatan ketuntasan hasil belajar per siklus nya dimana pada kondisi awal hanya 9 siswa atau 30\%, siklus I ada 15 siswa atau 50,00\%, dan pada siklus II ada 27 siswa atau $90,00 \%$, hasil ini sesuai dengan indikator yang ditentukan yakni minimal siswa tuntas mencapai $85 \%$ dari jumlah seluruh siswa. Rata-rata hasil belajar juga meningkat dari 66,67 menjadi 73,93 dan 84,67 pada siklus kedua. Hal ini menunjukkan bahwa pada siklus kedua rata-rata hasil belajar juga sudah memenuhi kriteria ketuntasan yaitu minimal sama dengan KKM sebesar 76,00.

\section{KESIMPULAN}

Dari hasil analisis data hasil penelitian tindakan kelas dengan menggunakan aplikasi Google Classroom dapat diambil kesimpulan:

Penggunaan aplikasi Google Classroom dapat meningkatkan prestasi belajar siswa kelas 9.D SMP Negeri 1 Duhiadaa pada pembelajaran IPA khususnya materi kemagnetan. Dari dua siklus pelaksanaan perbaikan pembelajaran yang dilaksanakan hasil belajar siswa menunjukkan kenaikan yang signifikan. Peningkatan hasil belajar siswa dari rata-rata pada studi awal hanya 66,67 naik menjadi 73,93 pada siklus pertama, dan 84,67 pada siklus kedua, dengan tingkat ketuntasan belajar sebanyak 9 siswa $(30,00 \%)$ pada studi awal, meningkat menjadi 50\% atau 15 siswa pada siklus pertama, dan 27 siswa atau 90,00\% pada siklus kedua sehingga dapat simpulkan bahwa semua indikator dan kriteria keberhasilan proses perbaikan pembelajaran telah terpenuhi dan tercapai pada siklus kedua. 


\section{SARAN}

Hasil pengamatan peneliti selama menggunakan aplikasi google classroom diajukan beberapa saran yaitu: Bagi guru Aplikasi google classroom dapat diimplementasikan di sekolah pada setiap mata pelajaran dan seluruh jenjang pendidikan. Bagi siswa, Dengan mengetahui penggunaan google classroom memberikan dampak positif pada hasil belajar pada mata pelajaran IPA. Bagi Sekolah Pelaksanaan pembelaja,ran google classroom era pandemic Covid-19 sebagai langkah awal untuk mempersiapkan perubahan modernisasi serta diharapkan mampu menjadi alternatif bagi SMP Negeri 1 Duhiadaa dalam mengatasi permasalahan pembelajaran sebagai dampak pandemi Covid 19.

\section{DAFTAR PUSTAKA}

A.M., Sardiman. 2001. Interaksi Dan Motivasi Belajar Mengajar. Jakarta: Raja. Grafindo Persada

Abdullah. 2018. Pemograman Web Untuk Pemula. Jakarta: Elex Media Komputindo.

Abruscato, J. 1996. Teaching Children Science: A Discovery Approach. Unite State of America: Allyn abd Bacon.

Aguinis, Herman. 2014. Performance Management. United States of America: Pearson.

Agus, Suprijono. 2012. Cooperative Learning: Teori dan Aplikasi Paikem. Yogyakrta: Pustaka Pelajar

Agusli, R., \& Azianah, R. M. 2014. Implementasi E-Learning Berbasis Web di SD Negeri Pasarkemis 1. Jurnal Sisfotek Global, 42, 61-63.

Akdon, Riduwan. 2007. Rumus dan Data dalam Aplikasi Statistika. Bandung: Alfabeta

Andi Permana. dkk. 2018. Effect Of Performance-Base Budgeting Good Getting, Internal Control, And Reporting On Performance Accountability Goverment West Lombok. International Conference And Call For Papers. Jember

Depdiknas. 2017. Panduan Pengembangan Pembelajaran IPA Terpadu. Jakarta: Puskur, Balitbang Depdiknas.

Dimyati dan Mudjiono. 2009. Belajar dan Pembelajaran. Jakarta: PT Rineka Cipta.

Fermiska dkk.,. 2020. Pembelajaran Daring Sebagai Upaya Study From Home SFH Selama Pandemi Covid 19. Jurnal Pendidikan Administrasi Perkantoran JPAP, 83, 496-503.

Fogarty, DW Blackstoner. Hoffman. 1991. Production \& Inventory Management 2edition.New York.

Halal, Swaesti. Buku Pedoman Pencegahan dan Penanganan Corona Virus. 1st ed. Emirfan, editor. Perpustakaan Nasional: Katalog Dalam Terbitan. Yogyakarta: Javalitera; 2020.

Hidayat, Nuruddin. 2009. Pengembangan Pembelajaran Terpadu Model Connected untuk Meningkatkan Hasil Belajar siswa dalam mata pelajaran IPA. Tesis : SPs UPI: tidak diterbitkan . Bandung

I.G.A.K. Wardani. 2007. Penelitian Tindakan Kelas. Jakarta: Universitas TerbukaKTSP SD/MI 2011

Iftakhar, Shampa. 2016. Google Classroom: What Works and How? Journal of Educationand Social Sciences, 3 feb, 12-18.

Iskandar, dkk. 2020. Aplikasi Pembelajaran TIK. Yayasan Kita 
Kemendikbud. 2013 Permendikbud No. 103 tentang pedoman pelaksanaan pembelajaran. Jakarta: Kemendikbud

Made Yeni Suranti, N. 2020. Variations of Models and Learning Platforms for Prospective Teachers During the COVID-19 Pandemic Period. Indonesian Journal of Teacher Education, 12, 61-70.

Mutia, I. 2013. Kajian Penerapan E-Learning dalam Proses. Faktor Exacta, 64, 278-289

Paizaluddin, dan Ermalinda. 2013. Penelitian Tindakan Kelas Classroom Action Resarch. Bandung: Alfabet

Pranajaya, 2018, Pembelajaran Jarak Jauh Berbasis Teknologi Informasi dan Komunikasi. Bandung. Alfabeta.

Rigianti, H. A. 2020. Kendala Pembelajaran Daring Guru Sekolah Dasar di Kabupaten Banjarnegara. 7, 297-302

Slameto. 2014. Primary School e-Learning Development as a Social Study Learning Model in the 5th Grade Primary School. International Journal of EEducation, e-Business, e-Management and e-Learning, 45, 351-360.

Supriyadi. 2013. Strategi Belajar Mengajar IPA. Yogyakarta : Jaya Ilmu.

Suwardi, Sarwiji. 2008. "Penelitian Tindakan Kelas dan Penulisan Karya Ilmiah". Surakarta : Panitia Sertifikasi Guru Rayon 13

Toharudin, Uus. 2011. Membangun Literasi Sains Peserta Didik. Bandung: humaniora Ucu, N. L., Paturusi, S. D. E., \& Sompie, S. R. U. A. 2018. Analisa Pemanfaatan ELearning Untuk Proses Pembelajaran. Jurnal Teknik Informatika, 131. 